\title{
Political consent, promissory fidelity and rights transfers in Grotius
}

\author{
Accepted manuscript, preprint, published in Grotiana (40), Brill, 2019
}

Grotius (1583-1645) is now widely acknowledged as an important figure in early modern contractual and consensual theories of political authority and legitimacy. ${ }^{1}$ However, as his thoughts on these debates are disseminated throughout his works rather than systematically ordained, it remains difficult to assess what, if anything constitutes his distinctive mark. In the present paper, I will argue that his works contain a combination of two conceptual elements that have come to constitute a salient characteristic of early modern contract and consent theories: first, a strong obligation to keep one's promises, and second, an account of perfect promises as transferrals of rights. In the political sphere, this means that citizens who have promised their obedience to the authorities are obligated to keep faith, which provides a solid foundation for political obligations. In addition, their promise implies that authorities receive the right to rule over them, which accounts for the legitimacy of these authorities' power.

Recent works by Blom, Eyffinger and Wilde have emphasised the central role of the obligation to keep faith in Grotius' legal, moral, and political theory. ${ }^{2}$ Indeed, he considers keeping promises crucial to peace within particular societies, as well as in international relations. Furthermore, according to him, states and their legal systems are instituted by agreements among citizens. ${ }^{3}$ As for the functions of promises, Grotius distinguishes between perfect and imperfect promises. Whereas imperfect promises create moral obligations for the promisor and no legitimate demands for the promisee, perfect promises enable a rights transfer from the promisor to the promisee. The reception of this idea was certainly facilitated by the diffusion of the notion of subjective rights, in which Grotius notoriously had an influential role. ${ }^{4}$ In political theory, citizens' promises of obedience imply that

\footnotetext{
${ }^{1}$ See in particular Désiré Schheltens, 'Grotius' Doctrine of the Social Contract', Netherlands International Law Review, 30/1 (1983), pp. 43-60; Jean Terrel, Les Théories du pacte social. Droit naturel, souveraineté et contrat de Bodin à Rousseau. Paris: Seuil, 2001, p. 100-115; Frank Grunert, 'Der Vertrag als rechtliches Medium sozialer Gestaltung. Zum Kontraktualismus bei Hugo Grotius', in: Konegen, Norbert / Nitschke, Peter (eds.) Staat bei Hugo Grotius. Baden-Baden: Nomos, 2005, pp. 125-139; Benjamin Straumann, Hugo Grotius und die Antike. Römisches Recht und römische Ethik im frühneuzeitlichen Naturrecht. Baden-Baden: Nomos, 2007, p. 195-201; Dominik Recknagel, Einheit des Denkens trotz konfessioneller Spaltung. Parallelen zwischen den Rechtslehren von Francisco Suárez und Hugo Grotius, Frankfurt am Main: Peter Lang, 2010, p. 163-236.

${ }^{2}$ Hans Blom, 'Sociability and Hugo Grotius', History of European Ideas, 41/5 (2015), pp. 589-604; Arthur Eyffinger, 'On Good Faith and Bad Faith: Introductory Note', Grotiana 36/1 (2015), pp. 79-105; Marc De Wilde, 'Fides publica in Ancient Rome and its reception', The Legal History Review, 79 (2011), pp. 455-487.

${ }^{3}$ De lure Belli, Prolegomena 15. As Brett phrases it (Annabel Brett, 'Natural Right and Civil Community. The Civil Philosophy of Hugo Grotius', The Historical Journal, 45/1 (2002), pp. 31-51, at p. 43): 'Grotius says that nature, the mother of natural right, can be considered the grandmother of civil right as well, in the sense that it is human nature and its principles which give the strength to natural human obligations. Hence there is a continuity in terms of formal justification through from nature to the city even though the equity/utility disjunction holds. Pact is the bridge which takes us over from the natural to the civil.'

${ }^{4}$ On Grotian rights, see Ross Harrison, Hobbes, Locke, and Confusion's Masterpiece. Cambridge: Cambridge University Press, 2003, p. 144-145; Knud Haakonssen, 'Hugo Grotius and the history of political thought', Political Theory 13 (1985), pp. 239-65, p. 240-241; Martin Harvey, 'Grotius and Hobbes', British Journal for the History of Philosophy, 14/1 (2006), pp. 27-50, at p. 33-36. The notion of subjective rights can be traced back to later medieval thought (Annabel Brett, Liberty, right and nature: Individual rights in later scholastic thought, Cambridge: Cambridge University Press 1997; Brian Tierney, The
} 
sovereigns receive their rights to govern themselves, which the citizens can no longer make use of.

The first part of this paper presents the philosophical arguments underlying Grotius' emphasis on the obligation to keep faith throughout his works (sections 1 to 3 ). The second part examines the structure of perfect promises as rights transfers (4). The third part points to the implications of the combination of these ideas for Grotius' political philosophy (5).

\section{De fide et perfidia (1601-1602): fides and freedom}

The obligation to keep one's word is already discussed in one of Grotius' earliest works, the chapter De fide et perfidia of the Parallelon rerum publicarum. Dutch trustworthiness is praised on every occasion, in contrast to the alleged perfidy of the Spanish and Portuguese. ${ }^{5}$ Grotius did not publish the work and later deemed it unsatisfactory. ${ }^{6}$ At that time, he used the term fides in a general meaning evoking moral integrity. ${ }^{7}$ The obligation to keep one's agreements is only part of fides, and a breach of obligations is but one example of perfidia, although he argues that a more specific term should be invented. ${ }^{8}$ In any case, fides must be observed in international relations and wars, for the sake of a natural community of mankind that imposes basic common norms upon humans (see below). For our paper, the most original element of De fide et perfidia is Grotius' claim that fighting for the sake of freedom, or fides, reflects the same mindset: 'May the entire world acknowledge that the advocacy of Freedom and Faith are in fact tokens of the same mentality. ${ }^{9}$ This evokes Grotius' eagerness to justify the Dutch resistance as as a struggle for freedom against the rule of the 'perfidious' ${ }^{10}$ Spanish; in his view, the Dutch resolve to expel their tyrannical oppressors would be a display of virtue.

De iure praedae (1605) and Meletius (1611): promise-keeping and truthfulness

\footnotetext{
idea of natural rights. Cambridge: Eerdmans, 1997). If Grotius did not invent it, it seems fair to suppose that the enduring popularity of his writings certainly contributed significantly to its establishment in legal and political theories.

${ }^{5}$ Wolfgang Fikentscher, 'De fide et perfidia: der Treuegedanke in den "Staatsparallelen" des Hugo Grotius aus heutiger Sicht', Munich: Bayerische Akademie der Wissenschaften, Heft 1. 1979, p. 31-32.

${ }^{6}$ On De fide et perfidia, see Fikentscher, 'De fide et perfidia'; Blom, 'Sociability and Hugo Grotius' and Eyffinger, 'On Good Faith and Bad Faith'.

${ }^{7}$ Fikentscher, 'De fide et perfidia', p. 11 and 97. See De Wilde, 'Fides public in Ancient Rome' for the various meanings of fides in ancient Rome.

${ }^{8}$ See Eyffinger's translation of De fide et perfidia in Grotiana 36/1 (2015), pp. 106-171, §11.

${ }^{9}$ Fikentscher 'De fide et perfidia', p. 35, 43 and 115.

${ }^{10}$ In De iure praedae, it is the Portuguese whom Grotius accuses of 'perfidy' (p. 374): 'Yet again, what is more abominable than perjury, or perfidy of any kind? [...] In earlier times, the Romans were wont to issue a statement breaking off friendly relations before they would declare war even upon those peoples against whom they had just cause to take up arms. The Portuguese, on the contrary, while engaged in devising acts of exceeding cruelty against the Dutch, and with the very purpose of facilitating the success of their cruel plans, were taking advantage of the disguise afforded by a pretence of friendship. But this manifestation of bad faith did not suffice them! Their outrageous conduct toward the Dutch reached the point of open defiance against the sacred insignia of peace, against pacts allowing of no ambiguity, against the holy obligations imposed by a sworn oath: in short, nothing was so sacrosanct that it could restrain the Portuguese from shedding the blood of Hollanders.'
} 
In De iure praedae (hereafter IPC), Grotius refers to a narrower sense of fides when it comes to promises. The third rule of Grotius' system of natural law in IPC is called regula fidei, and it refers to the obligations produced by promises: 'What each individual has indicated to be his will, that is law with respect to him' ${ }^{11}$ Quoting Cicero, Grotius adds that fides is 'the foundation of justice'. ${ }^{12}$ As Blom notes, fides refers here to trust and promissory fidelity (and not to a more general presumption of honest intentions, which would rather have been bona fides). ${ }^{13}$ Even on the other side of the world, promises must be kept by virtue of the bond (necessitudo) of mankind uniting Europeans and Non-Christians, even enemies. ${ }^{14}$ Moreover, Christians must keep faith to non-Christians to cast their religion in a positive light. ${ }^{15}$ Grotius alludes, in passing, to an additional aspect of fides: it is not only 'useful', but also 'a matter of honour'. ${ }^{16}$

IPC also contains important passages on the connection between promise-keeping, speech and truthfulness. Humans are the only creatures that have received speech from God. The main purpose of speech is to enable us to communicate our wills to each other. ${ }^{17}$ Accordingly, Grotius condemns all actions running against this purpose. Lying is sinful. In IPC, Grotius considers the norms of speech as 'the origin of pacts'.$^{18}$ It relates to justice, as defined by Simonides in Plato's Republic: 'To speak the truth, and to pay back what has been received. $^{19}$

Grotius does not provide a further account of the link between telling the truth and keeping one's word. Elsewhere in the IPC, humans are said to have a natural or rational inclination towards the truth. ${ }^{20}$ One possible interpretation of this link can be found in Aquinas's Summa Theologica (which we know Grotius read, although no evidence of influence on this particular matter can be asserted). In the Questions on truth and lies, Aquinas relies on a quotation from Cicero's De inventione: 'by truth we faithfully represent things as they are, were, or will be'. Grotius, as an admirer of Cicero, probably knew this passage as well. ${ }^{21}$

\footnotetext{
${ }^{11}$ De iure praedae commentarius (Liberty Fund edition, 2006), hereafter IPC, p. 34.

${ }^{12} \mathrm{Ibid}$. See De Officiis, 1,7,23. Cicero writes that fides requires constancy and truthfulness in our commitments. According to Cicero, the Stoics may be right in deriving the word fides from the injunction 'fiat quod dictum est'.

${ }^{13}$ Blom, 'Sociability and Hugo Grotius', p. 595. The word fides, of course, carries some extent of religious connotation due to its sense of religious belief in other contexts. In any case, the obligation to keep one's word is imposed upon us by God's will. On the relationships between religious faith and faith in contractual arrangements, see Okko Behrends, 'Treu und Glauben. Zu den christlichen Grundlagen der Willenstheorie im heutigen Vertragsrecht', in: Christentum, Säkularisation und modernes Recht, ed. by L.L. Vallauri and G. Dilcher, 2 vols. Baden-Baden: Nomos, 1981

${ }^{14}$ IPC, p. 453.

${ }^{15} \mathrm{lbid}$.

${ }^{16}$ Ibid.

${ }^{17}$ IPC, p. 34. As he tends to do, Grotius appeals to sources in a rather loose way. In Aristotle (Politics $\left.1,2,10\right)$, speech is meant to express what is useful and harmful and what is just and unjust. Having common notions of this nature unites a family or a state.

${ }^{18}$ IPC, p. 35.

${ }^{19}$ Ibid.; see also IBP 3,1,11; Republic $331 \mathrm{~d}$ - e. In Grotius' work, promises concern more than contractual arrangements transferring goods and creating debts (see below). Thus, I take Grotius' words about truth here to be relevant to his account of fides. This connection is confirmed in Meletius and the Inleiding.

${ }^{20}$ IPC, p. 119: '[...] those inclinations which are in the highest degree natural (such as the inclinations toward the True and toward the Good), as well as the others derived therefrom, exist inherently in some measure within all things. Here we have the source of such concepts as assured belief in posterity, the beneficial nature of property ownership, the credibility of witnesses or documents, and the gravity of oaths.'

${ }^{21}$ Summa Theologica, 2,2 Q. 109 Art. 1; Cicero, De inventione, 2,53. On Grotius' knowledge of the Summa Theologica, see Luis Alberto De Boni, 'Grotius and Scholasticism', in: Roberto Pich Hofmeister and Alfredo Santiago Culleton (eds), Right and
} 
Aquinas says that telling the truth constitutes a good act. It implies using 'signs which are in conformity with things'. ${ }^{22}$ In contrast, a lie consists of intentionally saying something one believes to be false. ${ }^{23}$ It is a lie to avoid keeping one's promise, and therefore a vicious act, unless one has promised 'ill'. ${ }^{24}$

Thus, this passage applies to an insincere promisor who says something about the future that she knows will not be realized because she does not intend to make it happen. In IPC, Grotius seems to share the assumption that we can tell some truth about future actions even without knowing the future itself - quite a puzzling assumption. Of course, further causes of promise-breaking can occur, such as changes of mind, weakness of will, forgetfulness or disregard for moral matters, all of which would seem wrong to him. It seems, in any case, that promise-breaking involves some kind of deception for him: 'For even if no additional injury is involved, it is in any case an evil to be deceived in one's belief. $^{25}$

The work Meletius provides additional answers to the question of what links promisekeeping, language and truth. Its aim was to show common characteristics of Christian confessions and to promote tolerance among them. ${ }^{26}$ Grotius reiterates that the heart of civil society lies the obligation to keep one's word. More importantly, this obligation is a divine command for Christians. God has granted us speech to foster the society of mankind, for speech allows us to communicate our thoughts to others (and not only our will, as in $I P C)$. Consequently, lying cannot be tolerated: it destroys the most useful contributor to society, namely the fact that we believe each other. Furthermore, nothing less than God's love for the truth is at stake:

[...] God loves truth so much that he wants us to say what we think and to do what we say. Everyone should therefore stick faithfully to all his covenants, unless you happen to have promised something forbidden by God, which was not within your power even before you gave the promise. ${ }^{27}$

\section{De iure belli ac pacis (1625) and Inleiding tot de Hollandse Rechtsgeleerdheid (1631): promises as tools}

Nature in the First and Second Scholasticism. Derecho y Naturaleza en la primera y segunda escolástica. Turnhout: Brepols Publishers, 2014, pp. 351-388, at p. 353-354.

${ }^{22}$ Ibid.

${ }^{23}$ Summa Theologica, 2,2 Q. 110 Art. 1.

${ }^{24}$ Summa Theologica, 2,2 Q. 110 Art. 3; see also James Gordley, The Philosophical Origins of Modern Contract Doctrine. Oxford: Clarendon, 1991, 11. It should also be noted that canon lawyers of the 16th century (such as Konrad Rittershausen) also wrote passages condemning promise-breaking in virtue of the sinfulness of lying (mendacium), which Grotius might have known (Behrends, 'Treu und Glauben', p. 991; Udo Wolter, Ius Canonicum in lure Civili. Köln: Böhlau-Verlag, 1975, p. 101).

${ }^{25}$ IPC, p. 34.

${ }^{26}$ Meletius was named after an Alexandrian Patriarch of the 16th century, 'who had tried to construct an ecumenical union of Christians against the influence of Islam' (Richard Tuck, Philosophy and Government 1572-1651. Cambridge: Cambridge University Press, 1993, p. 185). The treatise was long forgotten. As for literature on Meletius, see Julie Saada, 'Hugo Grotius et le jus circa sacra', in: Nicolas Piqué and Ghislain Waterlot (eds.), Réforme française et tolérance. Éléments pour une généalogie du concept de tolérance. Paris: L'Harmattan, 1999 and Jacqueline Lagrée, La raison ardente. Religion naturelle et raison au XVIle siècle. Paris: Vrin, 1991.

${ }^{27}$ Meletius §84; see Saada, 'Hugo Grotius et le jus circa sacra', p. 15. 
De iure belli ac pacis (hereafter IBP) maintains the connection between promise-keeping, sociability and speech in addition to emphasising their connection to reason: 'From this Society founded on Reason and Speech, arises that Obligation from a Promise [...]. ${ }^{28}$ Humans are endowed with a particularly strong appetitus societatis, which is attributed to their distinctive faculty: reason. ${ }^{29}$ Speech acts as an 'instrument ${ }^{30}$ to fulfil their desire for a sociable life in community. It allows them to enter into agreements, but also, in more general terms, to exchange thoughts: 'to which End Words were invented'. ${ }^{31}$

\section{The norms of speech}

Like Meletius, IBP contains injunctions derived from the importance of being able to believe one another, in accordance with the sociable purpose of speech. In Book II, Grotius explains that internal acts of will 'must be manifested by some external Sign', as 'the Thoughts of Man cannot be discovered but by outward Signs'. ${ }^{32}$ Yet difficulties may arise when it comes to the interpretation of one another's intentions and words ('Men may speak otherwise than they design or think, and by their Actions may give to understand a different Thing from what they have in their Thoughts'). ${ }^{33}$ Therefore, humans need rules for the interpretation of these outward signs:

\footnotetext{
But because the inward Acts and Motions of the Mind are not in themselves discernible, and there would be no Obligation at all by Promises, if every Man were left to his Liberty, to put what Construction he pleased upon them, therefore some certain Rule must be agreed on, whereby we may know, what our Promises oblige us to; and here natural Reason will tell us, that the Person to whom the Promise is given, has a Power to force him who gave it, to do what the right Interpretation of the Words of his Promise does require. For otherwise no Business could come to a Conclusion, which in moral Things is reckoned impossible. ${ }^{34}$
}

Accordingly, Grotius posits a 'natural Conjecture, whereby every one is supposed to intend that which he has sufficiently given to understand' ${ }^{35}$, i.e. declared 'by sufficient Signs ${ }^{\prime 36}$. It is popular use that should guide interpretation (citing Horace, 'Use is the Judge, the Law, and Rule of Speech'). ${ }^{37}$ In Book III, Grotius refers to a tacit pact to account for the wrongness of lying and the duty to be sincere (quasi pacto tacito, 'as by a silent Contract'). Grotius assumes that our interlocutor is entitled to the freedom to judge (libertas iudicandi) and

\footnotetext{
28 IBP 3,19,3.

29 IBP P. 7.

30 Ibid.

31 IBP 3,1,8

32 IBP 2,4,2.

${ }^{33}$ IBP 2,4,3.

${ }^{34}$ IBP 2,16,1,1. See also 2,4,3: 'However, as the Constitution of human Society does not permit the Acts of the Mind, sufficiently manifested, to remain without Effect, whatever one declares by sufficient Signs, passes for the real Thought and true Intention of him that uses those Signs. If his Words or Actions are contrary to his Intentions, so much the worse for him.'

${ }^{35}$ IBP 2,4,4,2.

${ }^{36}$ IBP 2,4,3: "whatever one declares by sufficient Signs, passes for the real Thought and true Intention of him that uses those Signs".

${ }^{37}$ IBP 2,16,2; Horace, The Art of Poetry, verse 70.
} 
hence access to our inward thoughts and intentions, at least the ones relevant to the 'Matter in Hand':

'For this, and no other, is that mutual Obligation, which Men intended to introduce by establishing the Use of Speech, and such other Signs; for without that such an Establishment had been to no Purpose. $^{38}$

This passage suggests that humans have somehow agreed to use speech in accordance with its purpose, namely successful communications that foster sociability. ${ }^{39}$ As Kahn phrases it, Grotius seems to refer to 'a linguistic contract - a contract about the meaning and right use of language', as 'the precondition of all other contracts' ${ }^{40}$ and as a 'bulwark against the anarchy of multiple, conflicting interpretations' ${ }^{41}$ Thus, linguistic norms are necessary prior to practices of mutual commitments, in order to sustain the establishment of the latter over time. However, once promises have turned into widespread practices, it also becomes possible to interpret certain actions as tacit expressions of a person's will, thanks to conventions, habits and customs, which may be invoked to support conjectures of her will. ${ }^{42}$ To take a political example, Grotius claims in IPC that the first members of a state initially gave their express consent to a collective agreement (pactis conventis) instituting it, and that members of subsequent generations came to give a "tacit indication (tacita significatione)" of their will to associate to their political community, and thus incurred the obligation of compliance that goes along with it. ${ }^{43}$ This illustrates that consensual obligations may be modelled on verbal interactions, but no longer require them once external circumstances can be taken to replace them.

\section{Promises as means}

In sum, Grotius has made it clear so far that sociability is the purpose of speaking and promising; accordingly, speech acts as a norm that regulates these activities. In the Prolegomena to the $I B P$, he proceeds to analyse the origin of promises from the perspective of their practical usefulness as well:

Again, since the fulfilling of Covenants [stare pactis] belongs to the Law of Nature, (for it was necessary there should be some Means of obliging Men among themselves [modus obligandi], and we

\footnotetext{
${ }^{38}$ IBP 3,1,11. See Martin Annen, 'Die Idee des "stillschweigenden Vertrages" und die Wahrhaftigkeitsfrage', in: Manfred Schneider, Die Ordnung des Versprechens. Munich: Wilhelm Fink, 2005, pp. 103-126, at p. 105-106 on this convention.

${ }^{39}$ Pufendorf will elaborate on the idea of a convention obliging us to use words both according to their usual meaning and our real intentions, such that we can know other people's wills and what to expect or demand from others: De jure naturae et gentium (1672), 4,1,4.

${ }^{40}$ Victoria Kahn, Wayward Contracts. The Crisis of Political Obligation in England, 1640-1674. Princeton: Princeton University Press, 2004, p. 37.

41 Ibid., p. 39.

${ }^{42}$ See IBP 2,16,1,2: "The best Rule of Interpretation is to guess at the Will by the most probable Signs, which Signs are of two Sorts, Words and Conjectures; which are sometimes considered separately, sometimes together." See lurlaro (lurlaro, Francesca, 'Grotius, Dio Chrysostom and the 'Invention' of Customary ius gentium', Grotiana, 39/1 (2018), pp. 15-44) on tacit consent in Grotius, especially in the case of custom.

${ }^{43}$ IPC p. 34; see also pp. 136-137.
} 
cannot conceive [fingere] any other more conformable to Nature) from this very Foundation Civil Laws were derived. ${ }^{44}$

This first shows that promises have their roots in utility. Humans need a stable source of obligations upon which they can rely. Thus, promises are tools that enable humans to benefit from practices of mutual commitment. The assumption here is that these practices are fundamental to human society, as we have seen in Grotius' earlier works. More specifically, humans must be able to create obligations towards other humans. Obviously, obligations towards God are not conditional on our choices. Consensual obligations, in contrast, have the purpose of shaping social interactions.

Second, promises are deemed the most natural means on which to ground these practices. At least, we could not think of a more natural one. As Harrison points out, the fact that we cannot imagine a more convenient means does not imply that there is not one. Starting from the idea that ' $[w]$ e have an idea of obligation, and we also wish to use such things', he suggests a reformulation of Grotius' idea:

It would be better to reconstruct this by saying that contracts (pacts, promises, agreements; the Latin here is pactum) are whatever it is whereby people agree in obligating themselves to each other. Then we don't need imagination about alternatives. We just need the simple fact that people wish to create mutual obligations. ${ }^{45}$

In the Inleiding tot de Hollandse Rechtsgeleerdheid, his work on Dutch law, Grotius appeals to our need for such practices to ground their obligating force. The obligation to keep one's word is declared crucial to any rational human community, as are virtues such as obedience and gratitude. ${ }^{46}$ There are three types of obligation (schuld) towards others: acting with benevolence (i.e., doing good to others, when this does not require "injuring" 47 oneself), keeping faith (trouw-schuld) and compensating for wrongs. ${ }^{48}$ The obligation to keep faith comes from speech, 'or anything that resembles speech [other signs, probably]' ${ }^{49}$ Again, speech is specific to humans and serves purposes of sociability. They have received it 'for the better furtherance of their common interest in order to make known what is hidden in the mind'. ${ }^{50}$ Truth occurs when the sign matches its object, and flows from the fact that language and mind are in harmony when an individual speaks. But our will is 'from its nature changeable'. ${ }^{51}$ For this reason, humans had to find a means to ' $\mathrm{fix}$ ' their wills: promises (beloften). ${ }^{52}$

The reasoning at work in this passage is the following. Our will can be formulated through linguistic means, including our will to create obligations that bind ourselves (by virtue of natural, and/or civil law). If we want to make our will known to others, we need to express

\footnotetext{
${ }^{44}$ IBP p. 16 (Prolegomena no. 15).

${ }^{45}$ Harrison, Ross, Hobbes, Locke, and Confusion's Masterpiece. Cambridge: Cambridge University Press, 2003, p. $142-143$.

${ }^{46}$ Inl. 3,1,3.

${ }^{47}$ Inl. $3,1,4$

${ }^{48}$ Inl. 3,1,3.

49 Inl. 3,1,5.

${ }^{50} \mathrm{lbid}$.

${ }^{51}$ Ibid.

${ }^{52}$ Ibid.
} 
it, for there is no other bridge between silent minds. But expressing our will means expressing an intention that exerts no influence on the future. Our words are true if they reveal a sincere intention, regardless of the fulfilment of this intention or not. Changes of will are licit and do not compromise the sincerity of our previous intentions. This position differs from that exhibited in IPC in that the scope of the truth no longer comprehends our future actions of compliance with our promissory obligations. The Inleiding presents the truth as a correspondence between actual intentions and words, or actions expressing them - a much less puzzling assumption.

The natural binding force of promises

Returning our attention to IBP, Grotius sets out to demonstrate, in the 11th chapter Of Promises, that promises are naturally binding. This challenges the posture of François Connan, a French humanist and jurist of the 16th century. ${ }^{53}$ Grotius identifies three reasons underlying Connan's claim that promises do not obligate per se. First, this claim invokes the promisee's responsibility: no one should believe a promise given without expecting something in return (a causa, consideration). Second, people would incur great losses if they had to meet all the commitments they made; most declarations are idle chatter anyway. Third, it would make much more sense to appeal to people's honour rather than to a strict obligation so as to leave them occasions to behave virtuously. ${ }^{54}$

If promises seem to be unserious commitments, to imply flippancy, and often turn out to be disadvantageous, should their obligating force be rejected? Grotius' objections do not address Connan's specific points, for he later writes that Connan has pollicitatio in mind, a sort of unilateral promise that creates no right in others (see below) ${ }^{55}$ Grotius prefers to attack the general view that promises have no natural obligating force. This starts with an appeal to practical reality: the view has the unacceptable consequence that international agreements have no value. And more importantly, a person's will to obligate herself must be taken as effective. Grotius refers to a famous motif (traced back to the Greek orator Demosthenes) that considers a nation's laws to be a 'common Covenant and Promise of the People'. ${ }^{56}$ Now, says Grotius, if the citizens' collective will has the power to make these laws binding, why should an individual's will not have the power to incur obligations binding himself (in virtue of the natural law)? On the whole, there is no reason to reject the force of an individual's promise if other voluntary commitments create obligations. ${ }^{57}$

Thus, the regula fidei of IPC remains germane ('What each individual has indicated to be his will, that is law with respect to him $^{\prime 58}$ ). Peoples agree to laws binding themselves, just as

\footnotetext{
${ }^{53}$ On what Connan wrote about promises, see also Malte Diesselhorst, Die Lehre des Hugo Grotius vom Versprechen. Köln: Böhlau, 1959, pp. 32-34 and Brett, 'Natural Right and Civil Community'.

54 IBP 2,11,1.

${ }^{55}$ IBP 2,11,6,2.

${ }^{56}$ IBP 2,11,1,3. On this motif, see François Quastana, 'La fortune de la maxime romaine « lex...est communis rei publicae sponsio » (D. 1. 3.1) dans la pensée juridico-politique européenne', in: L'idée contractuelle, XIXe colloque de l'Association Française des Historiens des Idées Politiques. Aix-en-Provence: Presses Universitaires d'Aix-Marseille, 2008, pp. 57-84.

${ }^{57}$ Ibid.

${ }^{58}$ IPC, p. 34.
} 
individuals do. ${ }^{59}$ This also supports Harrison's reading, according to which institutions regulating voluntary obligations originally spring from the human desire to create obligations binding themselves. To conclude IBP, Grotius urges rulers to keep faith. It is indispensable for peace, be it within a state or within the society of nations. In addition to Cicero and Aristotle, Grotius quotes Seneca: 'Faith is the most sacred Good of the rational Soul.' Sovereigns even face a stronger obligation than individuals to keep faith because they risk less immediate worldly sanctions. If the requirements of justice can be difficult to grasp at times, fides as promissory fidelity is 'self-evident'. ${ }^{61}$ And it preserves both our conscience and our reputation, whereas breaking faith repels humans and God. ${ }^{62}$

\section{Grotius' account of promises as transfers of rights}

As his response to Connan evinces, Grotius' conception of the obligation to keep one's word is closely related to his conception of promises. Here, we should note again that Grotius treats contracts and oaths as types of promises. ${ }^{63}$ Consent (consensus) is the act that gives rise to all of them. In this section, I examine the evolution of his account of promises throughout his works.

IPC already contains a key element of Grotius' account of promises: 'what is owed us is also said to be our property'. ${ }^{64}$ As Straumann highlights, this allows Grotius to innovate by introducing breach of faith as a cause of just war. If the withheld restitution of property constitutes a just cause, then so do debts arising from contracts, for they are part of our property. ${ }^{65}$ But why should debts be part of our property, and why do our actions form part of our property? The first step to elaborating an answer lies in human freedom of action:

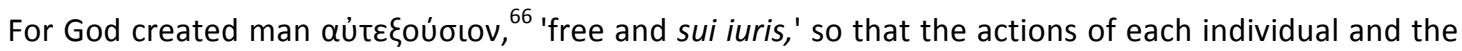
use of his possessions were made subject not to another's will but to his own. Moreover, this view is

\footnotetext{
${ }^{59}$ This passage is one of the instances of Grotius' frequent use of analogies between private and public legal matters. Throughout IPC and IBP, public and private wars share the same features. Indeed, public and private actors have the same rights and options to protect themselves; see Grunert 'Der Vertrag als rechtliches Medium', p. 132-133. Elsewhere, Grotius equates an individual's right to enslave himself to a people's right to submit entirely to the sovereign $(I B P 1,3,8)$, even though enslavement is about personal liberty, and submitting to a sovereign is about civil liberty. Lee thinks that the upshot of the analogy between public and private actors is his conception of the state as a fictive person bearing rights, Daniel Lee, 'Popular Liberty, Princely Government, and the Roman Law in Hugo Grotius's De Jure Belli ac Pacis', Journal of the History of Ideas, 72/3 (2011), pp. 371-392, at p. 379. See IBP 1,3,12 for the distinction between personal and civil liberty: 'But as there is a Difference between the regal Power, and that of a Master over his Slave; so likewise there is a Difference between civil Liberty, and that which is personal: The Liberty of a private Person is one Thing, and that of the whole Body of the People another. [...] As then personal Liberty excludes the Dominion of a Master, so does civil Liberty exclude Royalty, and all manner of Sovereignty properly so called. [...]'

${ }^{60}$ IBP 3,25,1,2.

61 lbid.

${ }^{62}$ IBP $3,25,1,3$.

${ }^{63}$ IBP 2,12,6. Grotius defines contracts as acts 'advantageous to others, except those which are of mere Generosity' (IBP $2,13,1)$. They create a 'society' between the parties, which is narrower than the society of mankind $(I B P 2,12,9)$. The obligations derived from contracts are accordingly stronger.

${ }^{64} I P C$, p. 103. Grotius refers here to the Digest, L, 16,91: 'Meorum et tuorum appellatione actiones quoque contineri dicendum est.'

${ }^{65}$ Straumann, Hugo Grotius und die Antike, p. 75. This holds both for individuals in private wars and nations in public wars. The idea can be found in IBP 1,1,5.

${ }^{66}$ Antexousion refers to self-determination.
} 
sanctioned by the common consent of all nations. For what is that well-known concept, 'natural liberty, ' other than the power of the individual to act in accordance with his own will? And liberty in regard to actions is equivalent to ownership in regard to property. ${ }^{67}$

The Inleiding completes this line of thought. In this text, Grotius also writes that an individual disposes freely of his actions (des mensches vrije macht over sijne daden), as of his property. This sets up the following argument: if it is licit to transfer some of my belongings to someone else, such as in the case of a contract, it is also licit to transfer a 'portion' (deel) or 'consequence' (gevolg) of my liberty (vrijheid) such that the recipient acquires a right to the action in question (a personal right, jus in personam) ${ }^{68}$ Hence, contractual obligations stem from individuals' power over their own actions. ${ }^{69}$

In IBP, a perfect promise (see below) is equivalent to the 'alienation' of our property. Indeed, we can alienate both things and parts of our liberty. ${ }^{70}$ The capacity to alienate what we own flows from the 'nature' of property. ${ }^{71}$ Indeed, Grotius conceives libertas as a type of power: a power over oneself (potestas in se) in comparison to a power over others (potestas in alios). $^{72}$

We have seen that Grotius thinks that an individual's will to obligate himself (in virtue of natural law) is similar to a collective commitment. The justification of the validity of the obligation appeals to a similar analogy, that also reminds us of his equation of liberty and ownership in $I P C^{73}$ :

Besides, since the Property of a Thing may be transferred by the bare Will, sufficiently declared, (as we have said before) why may we not in the same Manner transfer to one the Right, either of requiring us to transfer to him the Property of a Thing, (which is less than the actual Acquisition of the Right of Property itself) or of requiring us to do something in his Favour, since we have as much Power over our Actions as we have over our Goods? ${ }^{74}$

Hence, such promises are transfers of rights. ${ }^{75}$ Rights that were mine become yours, if I promise thus. And this explains why you can demand the fulfilment of my promise from me, or ask for compensation if I fail to keep my word: I am illegitimately keeping something that belongs to you and your claim to have it is valid. Such promises, like contracts, imply the creation of a debt, be it of material nature or not.

Conceiving promises as transfers of rights is significantly facilitated by Grotius' notion of subjective rights. If people own rights, they can transfer them or accept others' rights by acts

\footnotetext{
${ }^{67}$ IPC, p. 33-34.

${ }^{68}$ Inl. 3,1,4. This equation of liberty and property leads Pécharman to understand liberty in Grotius' sense as a 'thing' owned by people. Martine Pécharman, 'La vie ou la liberté? Le droit d'esclavage dans le droit naturel moderne', Droits 50/2 (2009), pp. 89-118, at p. 96.

${ }^{69}$ Inl. 3,1,28.

${ }^{70}$ IBP $2,11,4$.

${ }^{71}$ IBP 2,6,1.

${ }^{72}$ See Lee, Popular Liberty, p. 278.

${ }^{73}$ IPC, pp. 33-34.

${ }^{74}$ IBP 2,11,1,3.

${ }^{75}$ For a contemporary account of promises as transfers of rights with references to Grotius, see David Owens, 'Does a Promise Transfer a Right?', in: G. Klass, G. Letsas and P. Saprai (eds.), Philosophical foundations of Contract Law. Oxford: Oxford University Press, 2014, pp. 78-95.
} 
of consent, which ensures the legitimacy of the ensuing state of affairs. In IBP, one of the definitions of ius is a moral quality attached to a person. This quality makes it just for her to possess or do something, as delimited by the right in question. When this quality is perfect, it is called faculty (facultas). ${ }^{76}$ It consists of what jurists called the suum, namely our powers over ourselves and our property (i.e. our life, body, belongings). ${ }^{77}$ However, an aptitude (aptitudo) refers to ius as an imperfect moral quality: as Tierney puts it, a claim of reason or merit that could not be legally enforced. ${ }^{78}$

Now, what exactly counts as such a promise? Grotius distinguishes three 'Degrees or Manners of speaking about Things future' when it comes to what an individual believes to be in his power. ${ }^{79}$ The first degree comprehends mere assertions of intention that have no moral effects. The second degree refers to the Roman notion of pollicitatio, which Grotius terms an imperfect promise. An individual declares a lasting will to act in a certain way. That person is obligated to keep her word by the laws of nature, but no one can rightfully demand it from her, says Grotius. The third degree consists of perfect promises, which are binding as a matter of legal justice. A person declares her will to 'confer on another a real Right of demanding the Performance of [her] Promise' ${ }^{80}$ Here comes the alienation of her property, either of a thing or of a portion of her liberty. The promisee receives a perfect right (facultas), i.e. an enforceable right. ${ }^{81}$

The distinction between perfect and imperfect promises is even clearer in the Inleiding. There, a perfect promise is called a 'contract' (toezegging), an imperfect promise 'belofte' (i.e., a promise in the current sense): "Contract" is something more than promise. Promise has indeed the consequence that it is improper (onbehoorlick) not to perform what is promised, but does not give another party any right to accept the same. ${ }^{82}$ Hence, even though Grotius uses the same structure to account for all types of promises (ranging from moral commitments to legally binding contracts), the nature of the obligations differs. All commitments are binding in virtue of natural law, by moral necessity. Some commitments are binding in civil law as well: They are called perfect promises, and consist of transfers of rights as shown above. Which obligation is produced by the promise depends upon what we will to be obligated to, and which will we declare.

\section{Promissory fidelity and rights transfers in the political sphere}

As we have seen above, Grotius once states that there is no reason why an individual could not incur natural obligations binding his will, given that a people can do so. ${ }^{83}$ This means

\footnotetext{
${ }^{76}$ Ibid.

${ }^{77}$ Tierney, The Idea of Natural Rights, p. 325.

78 lbid.

${ }^{79}$ IBP 2,11,6.

${ }^{80} \mathrm{lbid}$.

81 IBP 1,1,3; 3,1,18: 'For every Promise, as I said before, confers a new and special right to the Person promised [...]'.

82 Inl. 3,1,11.

${ }^{83}$ IBP 2,11,1,3: 'Nor indeed can any Reason be given, why the Laws, which are, as it were, the common Covenant and Promise of the People (and so they are called by Aristotle and Demosthenes) should give such an obliging Force to
} 
that rights transfers can intervene in political contracts as well. More quotes below will indicate that he has indeed a perfect promise, and hence, a rights transfer in mind. As Brett has shown, 'the Grotian rights-based model has the advantage of being almost infinitely flexible': it allows him to take account of the diversity of existing state arrangements in Europe, as well as to 'defend the sovereign power of a variety of princes whose status as true sovereigns might otherwise seem questionable'. ${ }^{84}$ Indeed, in passages that are among the most often quoted parts of his work, Grotius claims that a people is free to choose the form of its government, and that the legitimacy of this government rests upon the specific rights that were transferred by the people to its sovereign:

But as there are several Ways of Living, some better than others, and every one may chuse which he pleases of all those Sorts; so a People may chuse what Form of Government they please: Neither is the Right which the Sovereign has over his Subjects to be measured by this or that Form, of which divers Men have divers Opinions, but by the Extent of the Will of those who conferred it upon him. ${ }^{85}$

This claim is reiterated later in the same chapter: in the Matter of civil Government, it is impossible to provide against all Inconveniencies; and we must judge of a Right, not by the Ideas that such or such a Person may form of what is best, but by the Will of him, that conferred that Right $[\ldots]^{\prime} .{ }^{86}$ There, he also evokes the transfer of rights to defend people's rights to vest their authorities with absolute power over themselves:

It is lawful for any Man to engage himself as a Slave to whom he pleases; as appears both by the Hebrew and Roman Laws. Why should it not therefore be as lawful for a People that are at their own Disposal, to deliver up themselves to any one or more Persons, and transfer the Right of governing them upon him or them, without reserving any Share of that Right to themselves? ${ }^{87}$

Before turning to our conclusions, it is also worth noting that this understanding of promises of obedience as rights transfers opens the way for reflections on the content of a subject's political obligations, as well as the limits of a sovereign's right to rule. For instance, Grotius already invokes this account of a rights transfer by means of a promise or pact in IPC when explaining why authorities have the right to punish their subjects' wrongdoings:

just as every right of the magistrate comes to him from the state, so has the same right come to the state from private individuals; and similarly, the power of the state is the result of collective agreement, as we demonstrated in our discussion of the Third Rule. Therefore, since no one is able to

Agreements; and yet, that a Man's own Will, endeavouring by all Means possible to oblige itself, cannot do the same Thing, especially in a Case where the Civil Law offers no Obstruction.'

${ }^{84}$ Annabel Brett, 'The Subject of Sovereignty: Law, Politics and Moral Reasoning in Hugo Grotius', Modern Intellectual History (2019, online first), 1-27, pp. 23-24.

${ }^{85}$ IBP $1,3,8$.

${ }^{86}$ IBP $1,3,17$. See also IBP 1,3,8: "Neither is the Right which the Sovereign has over his Subjects to be measured by this or that Form, of which divers Men have divers Opinions, but by the Extent of the Will of those who conferred it upon him." ${ }^{86}$

${ }^{87}$ IBP 1,3,8. On the Grotian right to self-governance, see Stephen Darwall, 'Grotius at the Creation of Modern Moral Philosophy', Archiv für Geschichte der Philosophie 94/3 (2012), pp. 296-325, at p. 316: 'The "well-known concept" of "natural liberty", is a reference to Fernando Vasquez, but however well established the idea of self-rule was in some form or other, it seems clear that Grotius took the idea of a natural right to govern oneself significantly farther. In Vasquez's hands, for example, "natural liberty" seems to refer alternately to a psychological faculty for free choice shared by rational agents, on the one hand, and to a Hohfeldian liberty, that is, to a range of permitted choices that violate no law or obligation, on the other. With Grotius, however, the right to rule oneself evidently includes a Hohfeldian claim right and therefore entails a consequent obligation of others to allow one to do so.' 
transfer a thing that he never possessed, it is evident that the right of chastisement was held by private persons before it was held by the state. ${ }^{88}$

As another example, when considering the question of whether soldiers may rightfully quit their post when facing danger of death, Grotius presumes that it is unlikely that 'the Intention of those who first entered into civil Society' would have been to 'impose on all Citizens the hard Necessity of dying', instead of maintaining the right to resist the sovereign's order in order to survive. Rather, 'it is very probable that Men have not received so extensive a Power [tantum ius accepisse] over themselves or others, except in Cases where extreme Necessity requires it' ${ }^{89}$

\section{Conclusion}

In summary, the present paper has highlighted two complementary lines of argumentation on consent in Grotius' works: first, his emphasis on the strength of the obligation to keep one's promises, and second, his conception of perfect promises as transfers of rights. Transposed to the political sphere, the combination of these ideas gives rise to a promise of obedience that can account both for the citizens' political obligations and the authorities' right to rule over the citizens, which, as I will argue below, constitute an important conceptual innovation.

As for the obligation to keep one's promises, Grotius' reflections appeal to several moral perspectives. Drawing upon his early works, promissory fidelity may be seen as a virtue intimately connected to other virtues such as integrity, truthfulness and sincerity (De fide et perfidia, IPC, Meletius). Even more importantly, in all of the works studied in the present paper, the obligation to keep one's promises is established from a teleological perspective, as a norm derived from the purpose of speech. As such, this norm is supposed to guarantee our ability to believe one another and to enter into mutual commitments (IPC, Meletius, IBP). Accordingly, when Grotius speaks of promises as means to fix one's will in order to enjoy the benefits of human commitments, he emphasizes the need to protect this means in order to preserve the availability of these indispensable benefits (IBP, Inleiding).

All of this shows that the strength of promissory obligations relates in several respects to the most crucial dimensions of human sociability. This may explain the role of promises as a foundation for political societies. In virtue of the cluster of arguments presented above, a promise of obedience must be kept. This means that such a promise is conceptually possible in a hypothetical state of nature, even before acquiring familiarity with the structures of political society. Therefore, the obligation to keep faith can indeed be the source of civil law,

\footnotetext{
${ }^{88}$ IPC pp. 136-137; see also pp. 133-134. The argument is still implicitly there in IBP, 2,20,9: 'And this [the right of punishing] is a Right that by the Law of Nature every one is invested with'; 'But yet, as in Revenge or Punishment inflicted for the Satisfaction of the offended Party, (whereof we have just now treated) so likewise, even in this Punishment, which is for Example, there remain some Footsteps of the antient Right in those Places, and amongst those Persons, who are not subject to any established Courts of Judicature; and even among those too who are so subject, in some particular Cases.'

${ }^{89}$ IBP $1,4,7$.
} 
as consent is able to produce obligations prior to its establishment. ${ }^{90}$ As to the effects of promises, Grotius constructs an account of perfect promises as transfers of rights based on the notion of liberty. By means of a promise, one can alienate a portion of one's liberty of action, just like a portion of one's property. The promisee receives a claim right to the corresponding action, and this action becomes part of her property.

In the political sphere, Grotius speaks of a citizen's perfect promise of obedience to his political authorities. What I wish to highlight in the Grotian account is that political consent has effects that pertain to two dimensions of political power that come to be correlated: political obligation and legitimacy. First, consent generates political obligations, as citizens voluntarily promise the sovereign a part of their liberty, i.e. future actions of compliance with the sovereign's commands. Second, consent also acts as a source of political legitimacy. As a result of this process, the sovereign receives and takes over the right to rule over the citizens, inasmuch as he obtains a right to future actions of compliance with his commands, and the right to use force to exact their due from citizens.

This Grotian combination of the obligation to keep one's word with a conception of perfect promises as rights transfers can also be found in subsequent accounts of political obligations involving consent, promises and contracts, most notably in the works of his immediate followers Hobbes and Pufendorf. Hobbes's well-known social contract rests on the natural law of promise keeping (the 'Fountain and Originall' of justice ${ }^{91}$ ), which enjoins one to keep one's promise to obey the sovereign. ${ }^{92} \mathrm{He}$ also makes use of the idea of a person transferring her right to govern herself to the sovereign: 'I authorise and give up my Right of Governing my selfe, to this man, or to this Assembly of men, on this condition, that thou give up thy Right to him, and Authorize all his Actions in like manner. ${ }^{93}$ Pufendorf discusses this as well, speaking of a transfer of the rights deriving from one's innate principle of selfgovernance (principium gubernandi se ipsum) ${ }^{94}$ : 'And as by private Contract, the Right of any thing which we possess, so by Submission the Right to dispose of our Strength and our Liberty of acting, may be convey'd to another. ${ }^{\prime 95}$ This typically happens when citizens 'engage their Allegiance [submiserunt]' by 'their own Act and Covenant [pacto]' ${ }^{96}$

Thus, the interpretation constructed in the present paper suggests that Grotius provides a conceptual structure that has found an echo in his followers' early modern consent and contract theories. This asset may be considered one of his contributions to the history of political thought.

\footnotetext{
${ }^{90}$ IBP P. 15; see Brett, 'Natural Right and Civil Community', pp. 40-43. On the state of nature in Grotius, see Straumann, Hugo Grotius und die Antike, pp. 34-39.

${ }^{91}$ Leviathan, Ch. 15 p. 100.

${ }^{92}$ See the Citizen, 14,10: 'natural law commands that all civil laws be observed in virtue of the natural law which forbids the violation of agreements', Leviathan Ch. 21 (p. 145), 'there happeneth in no Common-wealth any great Inconvenience, but what proceeds from the Subject's disobedience, and breach of those Covenants, from which the Common-wealth hath its being', and Ch. 30 (p. 232): 'For a civil law, that shall forbid rebellion, (and such is all resistance to the essential rights of the sovereignty), is not, as a civil law, any obligation, but by virtue only of the law of nature, that forbiddeth the violation of faith; which natural obligation, if men know not, they cannot know the right of any law the sovereign maketh.'

${ }^{93}$ Leviathan, Ch. 17 p. 120.

${ }^{94}$ De Jure Naturae et Gentium, 1,6,11.

95 Ibid., 7,3,1.

${ }^{96}$ Ibid., 7,2,5.
} 


\section{Bibliography}

Sources

Grotius, Hugo, On Good Faith and Bad Faith [De Fide et Perfidia (1602)], tr. by Arthur Eyffinger, Grotiana 36/1 (2015), pp. 106-171.

Grotius, Hugo, Commentary on the Law of Prize and Booty [De lure Praedae (1605)], tr. by Williams, Gwladys L., ed. by Martine Julia Van Ittersum, 2006. Indianapolis: Liberty Fund, 1950.

Grotius, Hugo, Meletius (1611), tr. by Guillaume Posthumus Meyjes (Leiden: Brill, 1988).

Grotius, Hugo, The Rights of War and Peace [De lure Belli ac Pacis (1625)], ed. and with an intr. by Richard Tuck (transl. into English (1738) from the French translation by Jean Barbeyrac (1724), based on Barbeyrac's 1720 Latin edition). Indianapolis: Liberty Fund, 2005.

Grotius, Hugo, Inleyding tot de Hollantsche rechtsgeleertheit (1631), tr. by R.W. Lee. Oxford: Clarendon, 1926.

Locke, John, Two Treatises of Government (1689), ed. by Peter Laslett, 2013 (1st ed. 1960). Cambridge: Cambridge University Press.

Pufendorf, Samuel von, The Whole Duty of Man According to the Law of Nature [De Officio (1673)], tr. by Andrew Tooke, ed. by lan Hunter and David Saunders, with Two Discourses and a Commentary by Jean Barbeyrac, tr. by David Saunders. Indianapolis: Liberty Fund, 2003.

Pufendorf, Samuel von,: Of the Law of Nature and Nations: Eight Books [De Jure Naturae et Gentium (1673)], ed. by L. Lichfield Oxford, 1710.

Rousseau, Jean-Jacques,: The Social Contract and Other Later Political Writings [Du contrat social (1762)], tr. by Victor Gourevitch. Cambridge: Cambridge University Press, 1997.

Suárez, Francisco, Selections From Three Works of Francisco Suárez, Vol. 2, Prepared by Gwladys L. Williams, Ammi Brown and John Waldron, with certain revisions by Henry Davis, S.J. and an introduction by James Brown Scott. Oxford: Clarendon Press, 1944.

De Vitoria, Francisco, Political Writings, ed. by Anthony Pagden and Jeremy Lawrance. Cambridge: Cambridge University Press, 1991.

\section{Literature}

Annen, Martin, 'Die Idee des "stillschweigenden Vertrages" und die Wahrhaftigkeitsfrage', in: Manfred Schneider (ed.), Die Ordnung des Versprechens. Munich: Wilhelm Fink, 2005, pp. 103-126.

Anscombe, G. E. M., 'On Promising and Its Justice, and Whether It Needs be Respected in Foro Interno', Crítica. Revista Hispanoamericana de Filosofía, 3/7 (1969), pp. 61-83.

Atiyah, P. S., The Rise and Fall of Freedom of Contract. Oxford: Oxford University Press, 1979.

Bärmann, Johannes, 'Pacta sunt servanda. Considérations sur l'histoire du contrat consensuel', Revue internationale de droit comparé, 13/1 (1961), pp. 18-53.

Behrends, Okko, 'Treu und Glauben. Zu den christlichen Grundlagen der Willenstheorie im heutigen Vertragsrecht', in: Christentum, Säkularisation und modernes Recht, ed. by L.L. Vallauri and G. Dilcher, 2 vols. Baden-Baden: Nomos, 1981.

Blom, Hans: 'Sociability and Hugo Grotius', History of European Ideas, 41/5 (2015), pp. 589-604.

Brett, Annabel, 'The Subject of Sovereignty: Law, Politics and Moral Reasoning in Hugo Grotius', Modern Intellectual History (2019, online first), pp. 1-27. 
Brett, Annabel, 'Natural Right and Civil Community. The Civil Philosophy of Hugo Grotius', The Historical Journal, 45/1 (2002), pp. 31-51.

Brett, Annabel, Liberty, right and nature: Individual rights in later scholastic thought, Cambridge: Cambridge University Press 1997.

Darwall, Stephen, 'Grotius at the Creation of Modern Moral Philosophy', Archiv für Geschichte der Philosophie 94/3 (2012), pp. 296-325.

De Boni, Luis Alberto, 'Grotius and Scholasticism', in: Roberto Pich Hofmeister and Alfredo Santiago Culleton (eds), Right and Nature in the First and Second Scholasticism. Derecho y Naturaleza en la primera y segunda escolástica. Turnhout: Brepols Publishers, 2014, pp. 351-388.

De Wilde, Marc, 'Fides publica in Ancient Rome and its reception', The Legal History Review, 79 (2011), pp. 455-487.

Diesselhorst, Malte, Die Lehre des Hugo Grotius vom Versprechen. Köln: Böhlau, 1959.

Eyffinger, Arthur, 'On Good Faith and Bad Faith: Introductory Note', Grotiana 36/1 (2015), pp. 79105.

Fikentscher, Wolfgang, 'De fide et perfidia: der Treuegedanke in den "Staatsparallelen" des Hugo Grotius aus heutiger Sicht', Munich: Bayerische Akademie der Wissenschaften, Heft 1. 1979.

Fried, Charles, Contract as Promise. Cambridge (MA): Harvard University Press, 1981.

Gordley, James, The Philosophical Origins of Modern Contract Doctrine. Oxford: Clarendon, 1991.

Goyard-Fabre, Simone, Le Droit et la Loi dans la philosophie de Thomas Hobbes. Paris: Klincksieck, 1975.

Grunert, Frank, 'Der Vertrag als rechtliches Medium sozialer Gestaltung. Zum Kontraktualismus bei Hugo Grotius', in: Norbert Konegen and Peter Nitschke (eds.) Staat bei Hugo Grotius. Baden-Baden: Nomos, 2005, pp. 125-139.

Haakonssen, Knud, 'Hugo Grotius and the history of political thought', Political Theory 13 (1985), pp. 239-65.

Harrison, Ross, Hobbes, Locke, and Confusion's Masterpiece. Cambridge: Cambridge University Press, 2003.

Harvey, Martin, 'Grotius and Hobbes', British Journal for the History of Philosophy, 14/1 (2006), pp. 27-50.

lurlaro, Francesca, 'Grotius, Dio Chrysostom and the 'Invention' of Customary ius gentium', Grotiana, 39/1 (2018), pp. 15-44.

Kahn, Victoria, Wayward Contracts. The Crisis of Political Obligation in England, 1640-1674. Princeton: Princeton University Press, 2004.

Lagrée, Jacqueline, La raison ardente. Religion naturelle et raison au XVIle siècle. Paris: Vrin, 1991.

Lee, Daniel, 'Popular Liberty, Princely Government, and the Roman Law in Hugo Grotius's De Jure Belli ac Pacis', Journal of the History of Ideas, 72/3 (2011), pp. 371-392.

Owens, David, 'Does a Promise Transfer a Right?', in: G. Klass, G. Letsas and P. Saprai (eds.), Philosophical foundations of Contract Law. Oxford: Oxford University Press, 2014, pp. 78-95.

Pécharman, Martine, 'La vie ou la liberté? Le droit d'esclavage dans le droit naturel moderne', Droits 50/2 (2009), pp. 89-118.

Quastana, François, 'La fortune de la maxime romaine « lex...est communis rei publicae sponsio » (D. 1. 3.1) dans la pensée juridico-politique européenne', in: L'idée contractuelle, XIXe colloque de I'Association Française des Historiens des Idées Politiques. Aix-en-Provence: Presses Universitaires d'Aix-Marseille, 2008, pp. 57-84.

Recknagel, Dominik, Einheit des Denkens trotz konfessioneller Spaltung. Parallelen zwischen den Rechtslehren von Francisco Suárez und Hugo Grotius, Frankfurt am Main: Peter Lang, 2010. 
Saada, Julie, 'Hugo Grotius et le jus circa sacra', in: Nicolas Piqué and Ghislain Waterlot (eds.), Réforme française et tolérance. Éléments pour une généalogie du concept de tolérance. Paris: L'Harmattan, 1999.

Straumann, Benjamin, Hugo Grotius und die Antike. Römisches Recht und römische Ethik im frühneuzeitlichen Naturrecht. Baden-Baden: Nomos, 2007.

Scheltens, Désiré Frans, 'Grotius' Doctrine of the Social Contract', Netherlands International Law Review, 30/1 (1983), pp. 43-60.

Terrel, Jean, Les Théories du pacte social. Droit naturel, souveraineté et contrat de Bodin à Rousseau. Paris: Seuil, 2001.

Tierney, Brian, The idea of natural rights. Cambridge: Eerdmans, 1997.

Tuck, Richard, Philosophy and Government 1572-1651. Cambridge: Cambridge University Press, 1993.

Wolter, Udo, Ius Canonicum in lure Civili. Köln: Böhlau-Verlag, 1975. 